\title{
Perbaikan Produksi dan Kualitas Buah Kakao Melalui Peningkatan Kompetensi Petani Di Desa Sepe Kecamatan Lage Kabupaten Poso
}

\author{
Andri Amaliel Managanta \\ Program Studi Agroteknologi Fakultas Pertanian Universitas Sintuwu Maroso \\ Corresponding author: andrimanaganta@gmail.com
}

\begin{abstract}
ABSTRAK
Desa Sepe termasuk wilayah pengembangan areal komoditas kakao di Kecamatan Lage Kabupaten Poso dan desa ini ke depan dapat dikembangkan menjadi desa kakao. Permasalahan yang dihadapi oleh petani di Kecamatan Lage Kabupaten Poso khususnya Desa Sepe adalah produksi buah kakao ditingkat petani masih rendah. Alternatif solusi melalui kegiatan penyuluhan, pendampingan mengenai teknik budidaya, pemanenan, dan pasca panen, pengolahan dan pemasaran buah kakao. Pengabdian ini bertujuan untuk memperbaiki kualitas hasil dan produksi kakao melalui peningkatan kompetensi petani baik melalui proses pemupukan, pemangkasan, pembersihan gulma secara teratur, pemanenan yang sesuai standar, dan pengendalian hama dan penyakit. Metode pelaksanaan meliputi pendampingan, demontrasi cara, kunjungan lapangan serta pendampingan dan monitoring evaluasi. Kegiatan ini merupakan hasil dari kegiatan pengabdian bagi masyarakat khusus di kebun kakao milik petani di Desa Sepe Kecamatan Lage Kabupaten Poso dan telah mampu meningkatkan 58 persen kuantitas hasil produksi $60 \mathrm{~kg} / \mathrm{bulan}$ dan penerimaan Rp.1.860.000/bulan.
\end{abstract}

Kata kunci: kakao, petani, penyuluhan, kompetensi, penerimaan

\begin{abstract}
Sepe Village is one of the cocoa commodity cultivation areas in Lage District, Poso Regency, and in the future, this village can be developed into a cocoa village. The problem faced by farmers in Lage District, Poso Regency, especially Sepe Village, is that cocoa production at the farm level is still low. Alternative solutions through extension, assistance on cultivation, harvesting, and post-harvesting techniques, processing, and marketing of cocoa fruit. This program to improve the quality of cocoa yields and production through improving the competence of farmers through the process of fertilizing, pruning, cleaning weeds regularly, harvesting according to standards, and controlling pests and diseases. Implementation methods include mentoring, demonstration of ways, field visits as well as mentoring and evaluation monitoring. This program is the result of community service activities specifically in farmers' cocoa farms in Sepe Village, Lage District, Poso Regency, and has been able to increase 58 percent of production yields to $60 \mathrm{~kg} / \mathrm{month}$ and IDR 1.860.000/month revenue.
\end{abstract}

Keywords: cocoa, farmers, extension, competence, revenue

\section{PENDAHULUAN}

Kabupaten Poso sebagai salah satu daerah pengembangan komoditas kakao di Provinsi Sulawesi Tengah. Data Badan Pusat Statistik (2019) diketahui bahwa luas areal komoditas kakao di Kabupaten Poso sebesar 39.104 hektar dengan produksi 25.639 ton. Desa Sepe termasuk wilayah pengembangan areal komoditas kakao di Kecamatan Lage Kabupaten Poso dan desa ini ke depan diharapkan dapat dikembangkan menjadi desa kakao. Permasalahan yang dihadapi oleh petani kakao di Kecamatan Lage Kabupaten Poso khususnya Desa Sepe adalah produksi buah kakao ditingkat petani masih rendah. Menurut Managanta et al. (2019), rendahnya produksi dan kualitas hasil kakao disebabkan oleh kompetensi petani dalam memelihara tanaman kakao masih kurang bahkan cenderung tidak melakukan kegiatan pemeliharaan. Hal tersebut tidak berbeda dengan petani di Desa Sepe. Oleh karena itu alternatif 
solusi dalam meningkatkan kompetensi dengan memberikan pemahaman tentang tanaman kakao dan peluangnya dalam meningkatan pendapatan petani. Salleh et al. (2015); Sumardjo, (1999); Managanta et al. (2018c) kompetensi meliputi kombinasi pengetahuan, keterampilan dan perilaku yang dipraktekan untuk perbaikan diri. Kompetensi juga merupakan pengetahuan, keahlian dan kemampuan yang dimiliki petani dan menjadi bagian dirinya sehingga dia bisa menjalankan usahataninya baik secara kognisi, afeksi dan perilaku psikomotorik.

Kompetensi dapat menyebabkan atau digunakan untuk melihat bahkan mengetahui kinerja petani, petani yang mempunyai kompetensi yang tinggi akan mempunyai kinerja tinggi dan usahatani yang diusahakan dapat berhasil. Hal ini dilakukan melalui kegiatan penyuluhan, pendampingan mengenai teknik budidaya, pemanenan, dan pasca panen, pengolahan dan pemasaran buah kakao (Managanta et al., 2018a). Untuk menambah wawasan dan pengalaman yang dapat membangkitkan motivasi petani dalam melaksanakan usahatani kakao. Selain itu tingkat serangan hama dan penyakit yang tinggi menyebabkan banyak kakao yang rusak, akibatnya harga jual kakao dan tingkat pendapatan petani berkurang. Adapun dampak yang diharapkan dari pelaksanaan kegiatan ini terhadap petani kakao dan masyarakat sekitarnya antara lain: (1) perbaikan kualitas tanaman kakao dan berdampak pada peningkatan produksi, dan (2) peningkatan penerimaan maupun pendapatan petani kakao.

Kakao mempunyai peran strategis dalam perekonomian masyarakat di Desa Sepe, meskipun demikian secara umum permasalahan yang dihadapi petani kakao di desa tersebut adalah produksi buah kakao ditingkat petani masih rendah karena sikap petani dalam memelihara tanaman kakao masih kurang, bahkan cenderung tidak lagi memerhatikan usahatani kakao sebagai sumber pendapatan utama petani. Menurut Managanta et al. (2018b), terbatasnya penyuluhan yang di dilakukan bukan berdasarkan kebutuhan petani sebagai salah satu faktor rendahnya kompetensi dan keinginan petani memperhatikan usahatani kakao. Peningkatan produksi tidak hanya diperoleh melalui peningkatan teknologi, peningkatan produksi dapat didukung oleh peningkatan kompetensi petani. Oleh karena itu, pengabdian ini bertujuan untuk memperbaiki kualitas hasil dan produksi kakao melalui peningkatan kompetensi petani baik melalui proses pemupukan, pemangkasan, pembersihan gulma secara teratur, pemanenan yang sesuai standar, dan pengendalian hama dan penyakit. Dengan kompetensi yang baik, petani dapat memperbaiki kegiatan-kegiatan usahatani dan pada akhirnya petani mampu meningkatkan produksi dan penerimaan usahatani.

\section{METODE}

Metode yang digunakan pada kegiatan pengabdian ini adalah metode penyuluhan melalui pendekatan individu (Ban dan Hawkins, 1999); (Sumardjo, 2006). Terdiri dari pelatihan dan pembinaan, transfer inovasi, dan monitoring maupun evaluasi. Kegiatan pelatihan dan pembinaan kepada petani kakao meliputi penyuluhan dan diskusi, demonstrasi dan praktek serta konsultasi dan pendampingan. Kegiatan penyuluhan dan diskusi dilakukan dengan menentukan petani kakao dalam mengikuti penyuluhan dan diskusi tentang proses budidaya, pemanenan, pascapanen, dan pengolalaan maupun pemasaran. Kegiatan transfer inovasi dilakukan sesuai kebutuhan petani. Ini untuk mengatasi permasalahan menurunnya produksi dan kualitas biji kering kakao. Monitoring dan evaluasi dilakukan untuk mendapatkan efektivitas kegiatan dengan cara mengamati dan menganalisis proses berjalannya kegiatan. Kegiatan ini dilakukan pada kebun milik petani Raden Saleh Bantau yang ada di Desa Sepe Kecamatan Lage Kabupaten Poso. Kegiatan ini dilakukan secara periodik untuk membina dan mendampingi petani Raden Saleh Bantau sampai berhasil dalam mengubah perilaku berusahatani. Pengabdian bagi masyarakat dilaksanakan pada bulan Januari sampai Desember 2019 di Desa Sepe Kecamatan Lage Kabupaten Poso pada kakao berumur 7 (tujuh) tahun. Sedangkan kuesioner digunakan untuk mengukur tingkat keberhasilan kegiatan pengabdian baik sebelum dan sesudah pelaksanaan serta mengukur tingkat pengetahuan dan keterampilan hingga produksi dan penerimaan petani. Menurut Sumardjo (1999); Managanta (2018) hasil pengukuran untuk pengujian secara statistik dan agar data yang terkumpul mempunyai kisaran nilai yang sama, yaitu nilai $0-100$, maka dilakukan proses transformasi. 
Indeks transformasi indikator:

$$
\text { Indeks Transformasi }=\frac{\text { Jumlah Skor yang Tercapai }- \text { Jumlah Skor Minimal }}{\text { Jumlah Skor Maksimal }- \text { Jumlah Skor Minimal }} \times 100
$$

Hasil indeks transformasi indikator yang dinormalkan

$$
\text { Indeks Transformasi }=\frac{\text { Indeks Transformasi Indikator }}{\text { Skor Hasil Rata }- \text { Rata }}
$$

\section{HASIL DAN PEMBAHASAN}

Kegiatan pengabdian dilakukan pada kebun milik petani Raden Saleh Bantau yang ada di Desa Sepe Kecamatan Lage Kabupaten Poso. Kegiatan pengabdian dimulai dengan melakukan observasi lokasi, melibatkan Raden Saleh Bantau sebagai pemilik. Hal ini bertujuan mengidentifikasi kebutuhan pelatihan dan pembinaan, demostrasi dan transfer inovasi. Pemilik menyebutkan kakao sudah ditanam sejak tahun 2013 dan sudah melalui proses sambung pucuk. Beberapa permasalahan yang ditemukan di lokasi pengabdian: (1) kurangnya perawatan; (2) rendahnya produksi; (3) serangan hama dan penyakit (Gambar 1). Pelaksanaan pengabdian berbasis paradigma penyuluhan yang bersifat partisipatif (partisipatory) atau berfokus pada pengembangan sumber daya manusia dalam hal ini petani Raden Saleh Bantau dan melalui pendekatan bottom up. Sejalan dengan itu menurut Cahyono \& Adhiatma, (2012), kekuatan kerjasama ini akan maksimal jika didukung oleh semangat proaktif diatas prinsip-prinsip sikap yang partisipatif, saling percaya mempercayai, dan diperkuat oleh nilai-nilai dan norma-norma.

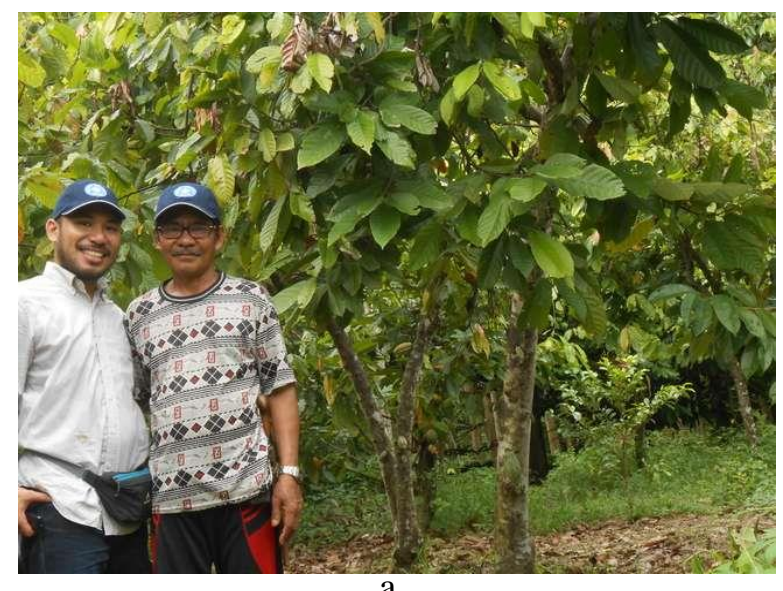

a

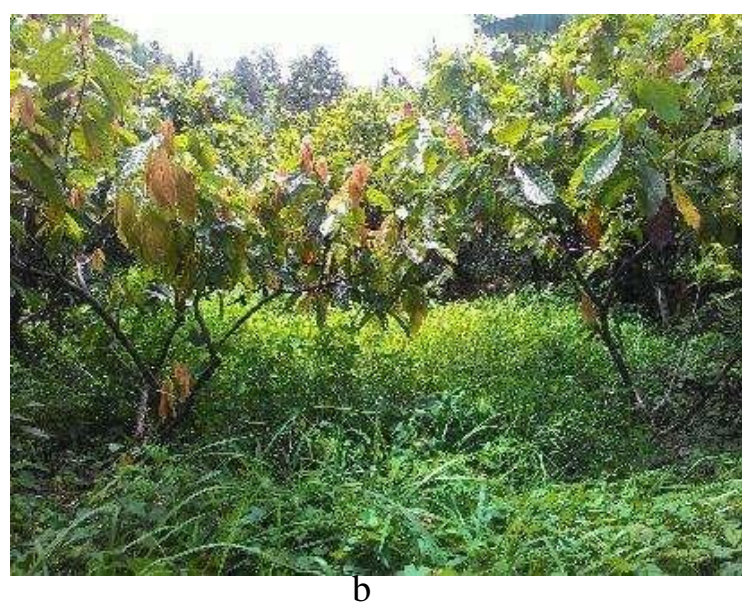

Gambar 1. (a) Observasi lokasi pengabdian (b) Kebun Raden Saleh Bantau di Desa Sepe Kecamatan Lage Kabupaten Poso

Proses pengabdian membantu petani dalam meningkatkan kompetensi petani melalui pelatihan pemupukan, pemangkasan, pembersihan gulma secara teratur, proses panen sesuai standar, dan pengendalian hama maupun penyakit. Untuk meningkatkan pengetahuan dan keterampilan budidaya kakao yang baik dilakukan kunjungan lapang, demonstrasi dan praktek pemupukan. Kegiatan tersebut diikuti oleh Raden Saleh Bantau sebagai pemilik lahan. Sanitasi atau pembersihan lahan dilakukan untuk membersihkan areal perkebunan kakao milik petani dari segala gulma dan tanaman yang tidak dibutuhkan (Gambar 2).
Pembersihan dilakukan untuk membersihkan kebun kakao agar terlihat bersih dan enak dipandang, mengendalikan hama kakao, jika kotor maka hama penyakit akan mudah berkembang biak. Selain pembersihan lahan, pelaksana dan pemilik lahan melakukan pemangkasan yang bertujuan untuk membentuk kerangka dasar tanaman kakao yang seimbang dengan hanya menyediakan tiga sampai empat cabang utama, mengatur penyinaran matahari, mendorong pembentukan daun baru dan merangsang pembungaan serta pembentukan buah kakao. Penjelasan tentang budidaya dan pemangkasan yang baik, serta pengendalian 
organisme penganggu tanaman. Pelaksana juga menjelaskan pentingnya pembuatan percabangan karena berhubungan dengan jumlah buah yang dihasilkan. Selanjutnya cabang tersebut dipelihara sebaik-baiknya untuk dapat menghasilkan tajuk yang baik dengan ketinggian tanaman yang tidak terlalu tinggi (Gambar 2).

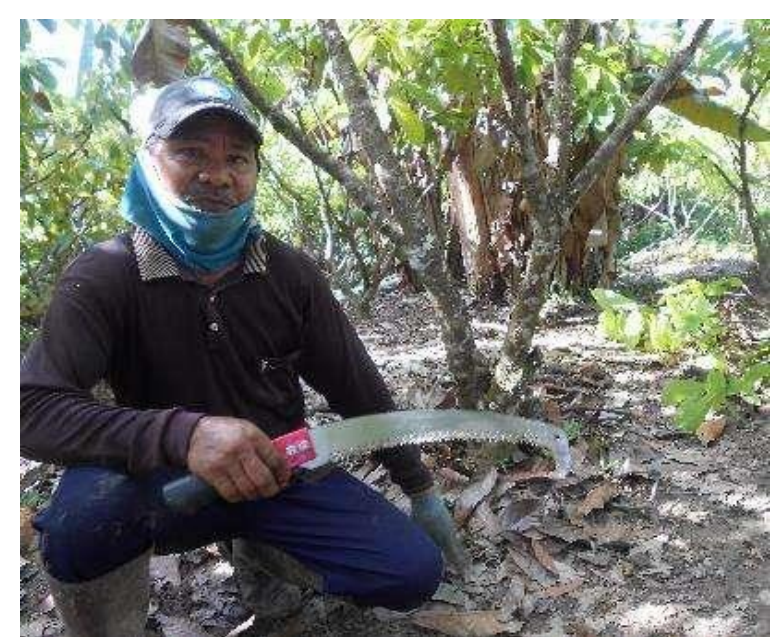

a

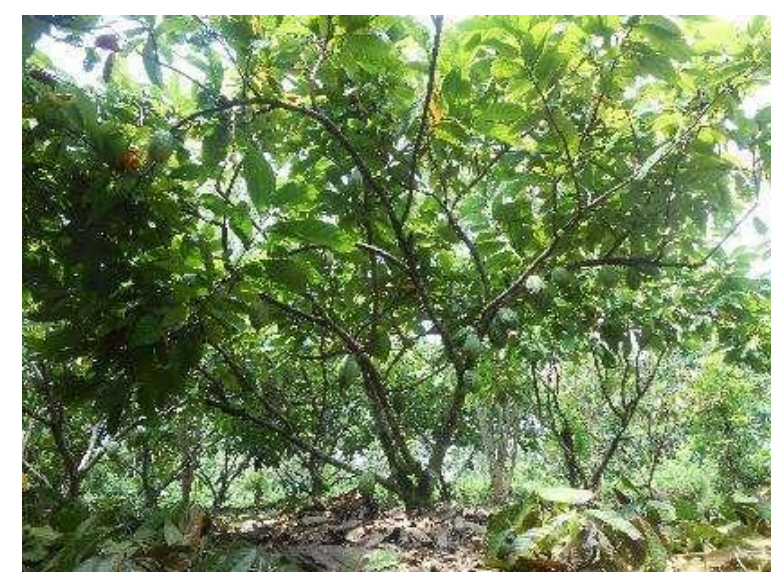

c
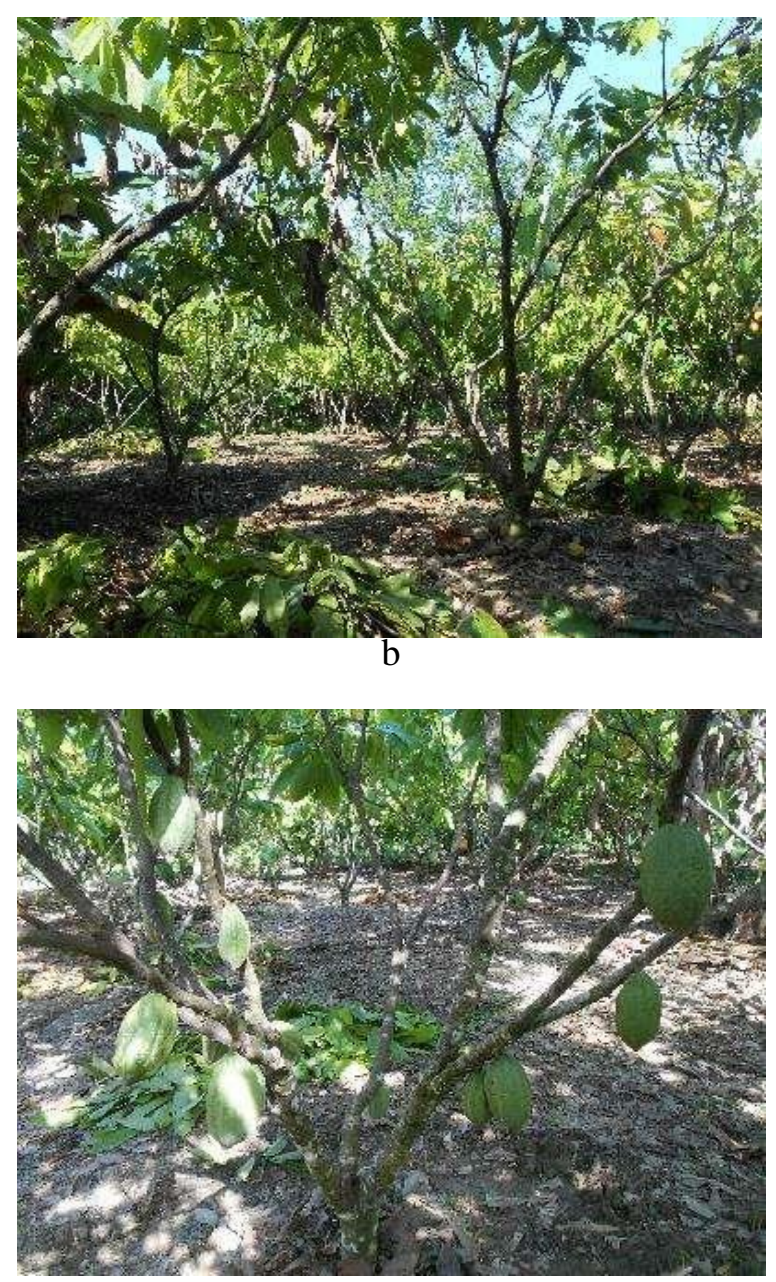

d

Gambar 2. (a) Bersama Raden Saleh Bantau mempersiapkan proses pemangkasan dan pembersihan; (b) Proses pemangkasan dan pembersihan lahan; (c) Pemangkasan kakao; (d) kakao yang telah dilakukan pemangkasan

Pemupukan kakao merupakan kegiatan budidaya yang penting dalam meningkatkan produksi buah milik petani. Pemberian pupuk dibenamkan dalam tanah karena cara tersebut merupakan cara yang paling baik karena di samping pupuk aman tidak menguap juga tidak terlalu banyak pupuk yang dibutuhkan dan frekuensi pemberiannya cukup dua kali setahun. Proses pemupukan bertepatan dilaksanakan pada awal musim hujan sehingga pupuk diserap oleh tanaman karena kandungan air dalam tanah tersedia. Pelaksana menyediakan pupuk anorganik (pupuk kimia) Phonska dan SP-36 serta pupuk organik Mitra Flora untuk pupuk bunga, daun dan buah (Gambar 3).
Buah kakao yang berkualitas biasanya dihasilkan dari bunga-bunga yang tumbuh pada batang pokok dan biasanya menghasilkan kualitasnya baik. Berdasarkan pengamatan dan diskusi dengan petani Raden Saleh Bantau, ratarata hasil kakao yang matang dan siap di panen membutuhkan waktu selama 4-5 bulan. Pemanenan menggunakan gunting setek atau gunting pangkas dan menyisahkan tangkai dengan panjang sekitar $1-1,5 \mathrm{~cm}$. Pada saat pelaksanaan pengabdian dan pengamatan, petani tidak lagi melakukan pemanenan dengan memutar buah (Gambar 4). Pada tahap ini, pelaksana dan petani Raden Saleh Bantau melakukan pemeraman (fermentasi) pada biji. 


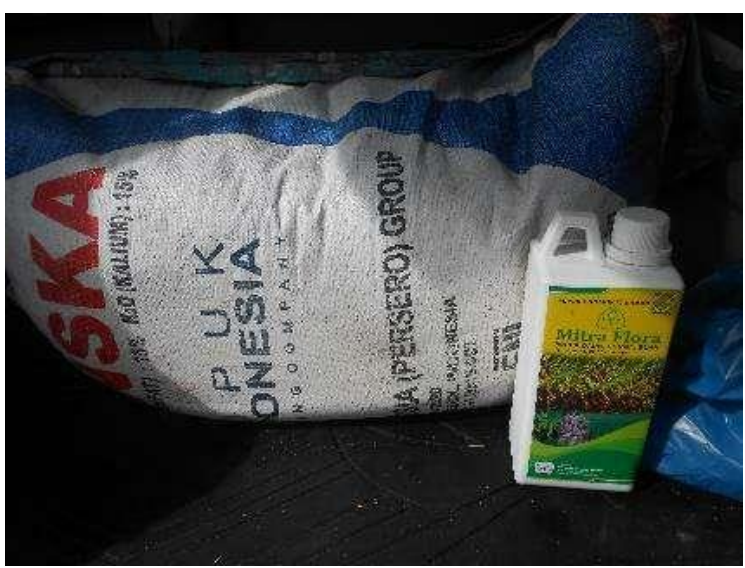

a

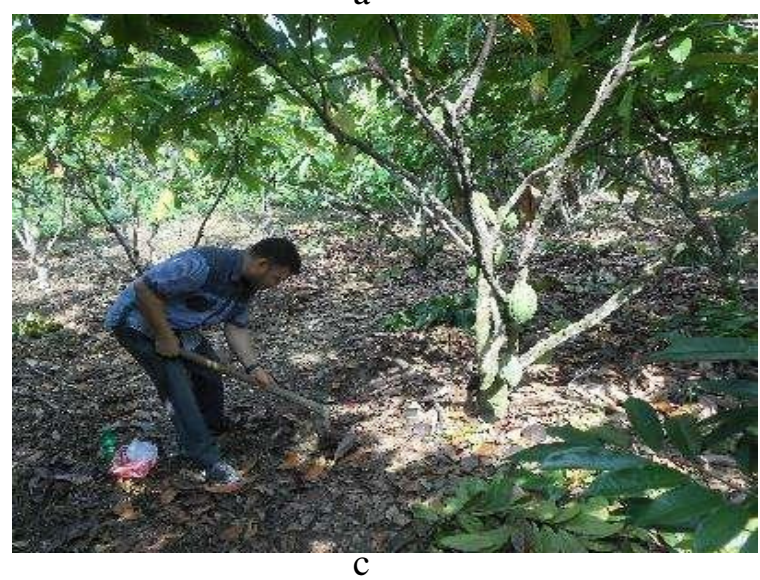

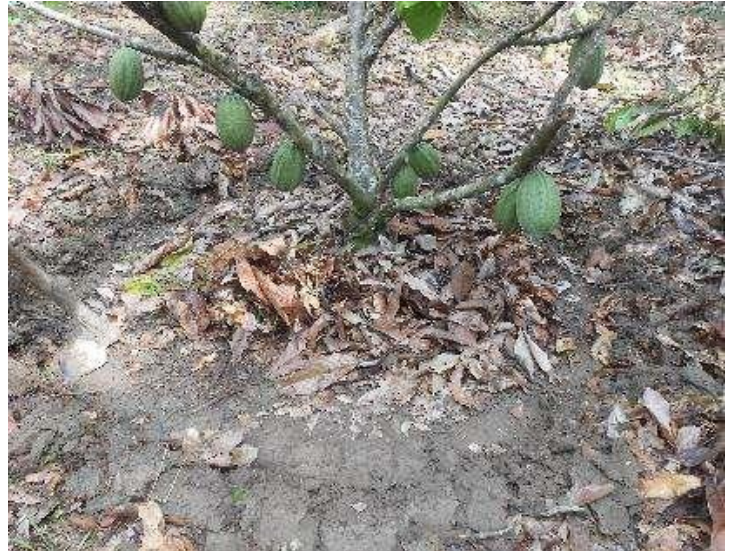

b

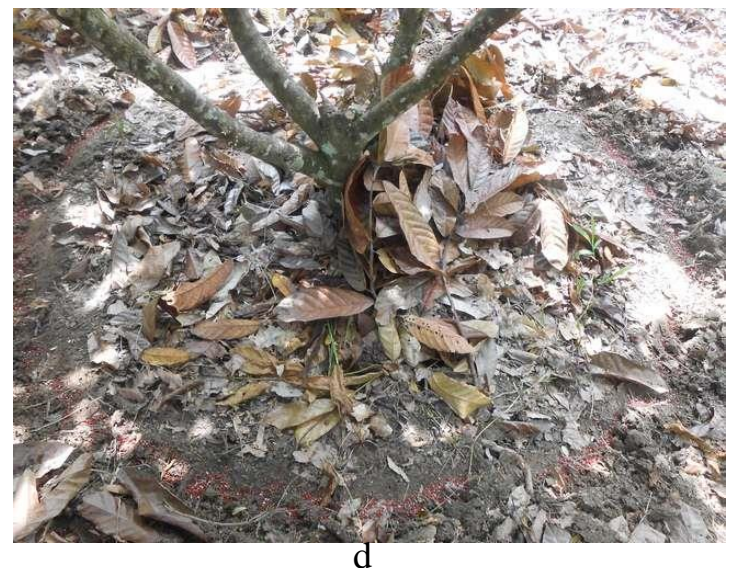

Gambar 3. (a) Pengadaan pupuk phonska, SP36 dan pupuk organik Mitra Flora oleh pelaksana; (b) pembuatan larikan oleh pelaksana dan pemilik kebun Raden Saleh Bantau; (c) Pemupukan oleh pelaksana dan pemilik kebun Raden Saleh Bantau di Desa Sepe Kecamatan Lage Kabupaten Poso

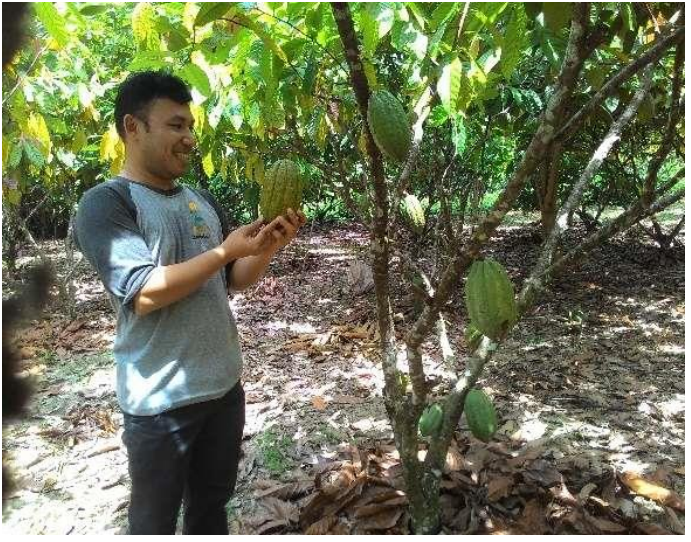

a

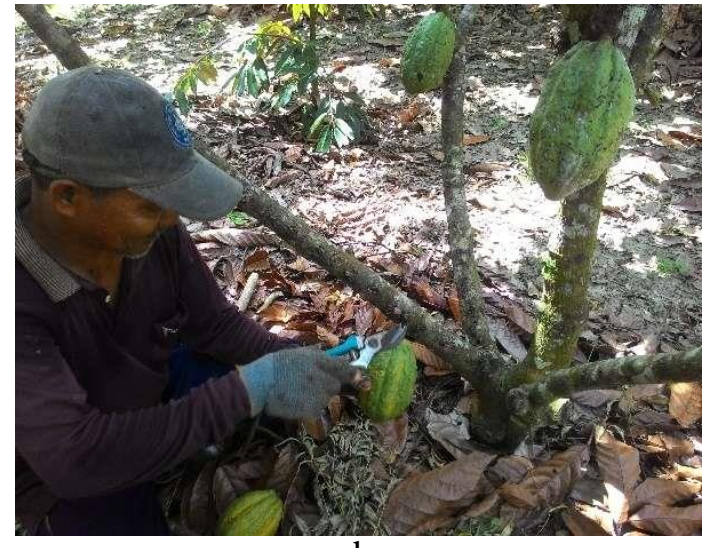

b

Gambar 4. (a) Pelaksana memerhatikan buah yang dapat dipanen; (b) Raden Saleh Bantau melakukan proses pemanenan menggunakan gunting panen

Menurut Hasibuan et al. (2012), pelaksanaan fermentasi biji kakao dapat meningkatkan daya saing produk kakao. Setelah proses pemeraman 1-2 hari, biji kakao dilakukan penjemuran untuk menurunkan kadar air biji kira-kira sampai 6-7 persen. Pemeraman dan pengeringan dengan menjemur biji dibawah terik matahari merupakan metode yang paling baik dan menurut petani murah. Penjemuran dilakukan di atas jaring (paranet). Kegiatan di lapangan diikuti dengan monitoring dan evaluasi kepada petani untuk memastikan proses transfer teknologi dapat maksimal (Gambar 5). 


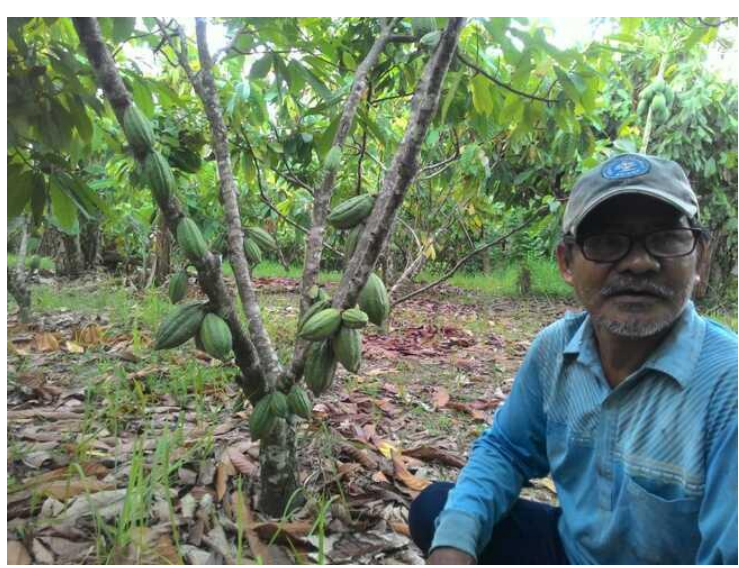

a

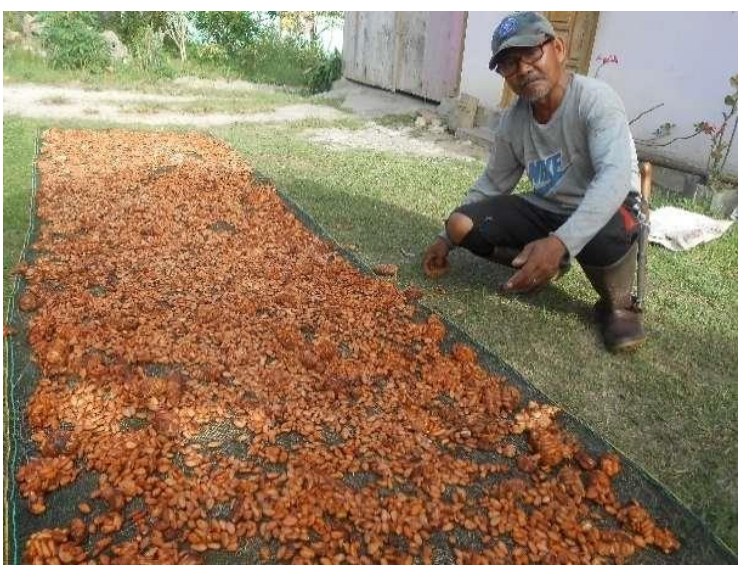

c

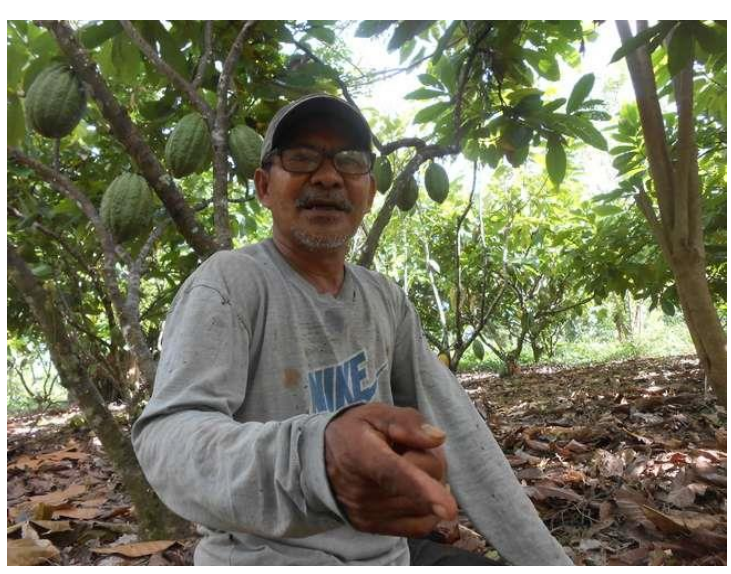

$\mathrm{b}$

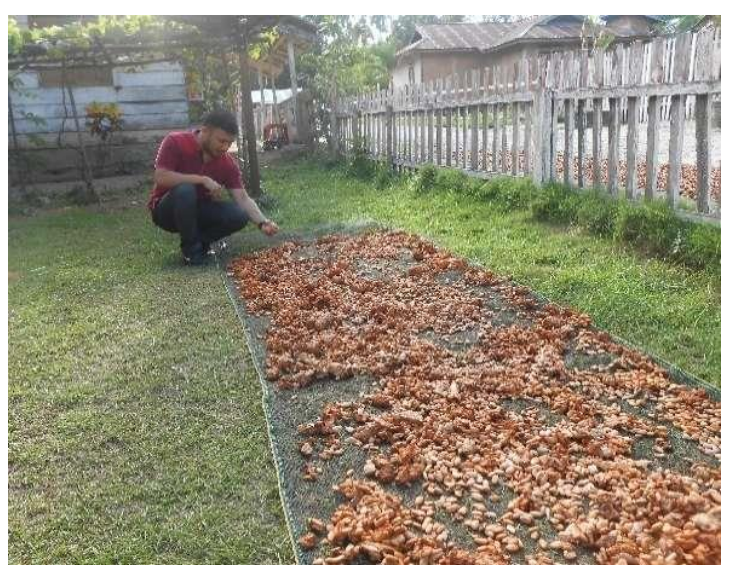

d

Gambar 5. (a) Pelaksanaan monitoring dan evaluasi; (b) Pelaksanaan monitoring dan evaluasi (c) Pelaksanaan penjemuran buah kakao; (d) Pelaksana bersama Raden Saleh Bantau melaksanakan penjemuran biji kakao

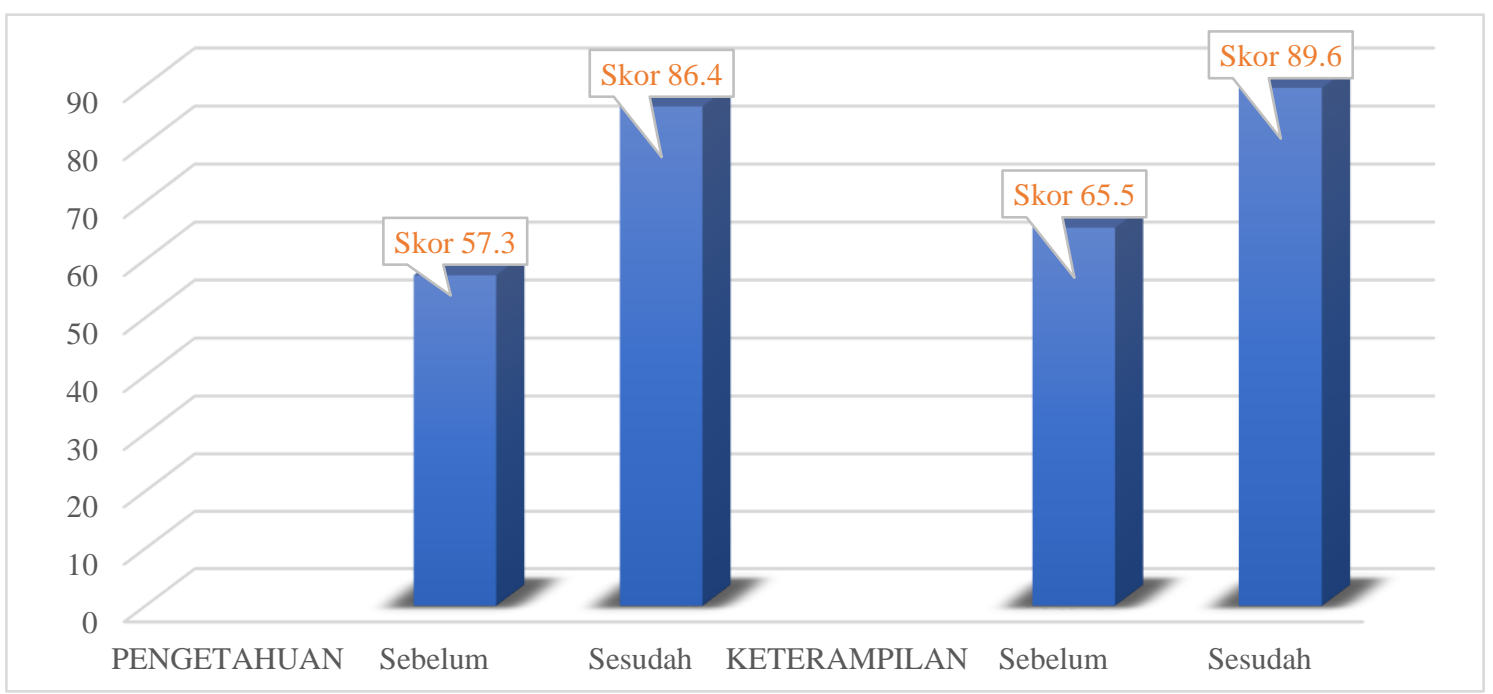

Gambar 6. Peningkatan pengetahuan dan keterampilan petani sebelum dan sesudah pelaksanaan pengabdian kepada masyarakat

Berdasarkan wawancara bersama Raden Saleh Bantau, petani menyatakan sebelum dan sesudah pelaksanaan pengabdian terjadi perbedaan pengetahuan dan keterampilan maupun hasil (Gambar 6). Wawancara bersama petani menunjukkan terjadi peningkatan intensitas pemangkasan, pembersihan gulma, penggunaan pupuk dan proses pascapanen yang 
baik. Penyakit busuk buah kakao dapat diatasi dengan perawatan tanaman intensif begitupun pemetikan buah kakao yang sebelumnya dengan cara memelitir berubah ke penggunaan gunting panen yang tujuannya menjaga kualitas buah. Tidak dapat dipungkiri peningkatan produksi juga dipengaruhi oleh semua proses yang telah dilaksanakan petani baik pemangkasan sampai pada proses pascapanen. Informasi dari petani, sebelum dilaksanakan pengabdian rata-rata biji kering yang dihasilkan $35 \mathrm{~kg}$ per bulan dan setelah pelaksanaan pengabdian mengalami peningkatan rata-rata $60 \mathrm{~kg}$ per bulan atau kuantitas meningkat 58 persen dengan harga berkisar Rp 29.000 - Rp 31.000 per kg atau penerimaan rata-rata per bulan $\mathrm{Rp} 1.860 .000$.

\section{KESIMPULAN}

Hasil pengabdian dapat disimpulkan bahwa terjadi peningkatan perbaikan kualitas hasil dan produksi melalui peningkatan kompetensi. Hal tersebut didukung oleh proses pemupukan yang sesuai, pemangkasan teratur, pembersihan gulma yang diperhatikan dan pemanenan yang sesuai standar. Kegiatan pengabdian bagi masyarakat di kebun kakao milik petani di Desa Sepe mampu meningkatkan kualitas dan kuantitas hasil produksi menjadi 60 $\mathrm{kg} /$ bulan atau meningkat 58 persen dan penerimaan Rp.1.860.000/bulan. Pelaksanaan pengabdian melalui paradigma partisipatif (partisipatory) dengan pendekatan bottom up melalui proses penyuluhan dapat meningkatkan produksi dan penerimaan petani.

\section{UCAPAN TERIMA KASIH}

Penulis menyampaikan terima kasih kepada Universitas Sintuwu Maroso yang mendanai kegiatan pengabdian tahun anggaran 2019 dan kepada Pemerintah Desa Sepe atas arahan dan persetujuannya. Secara khusus kepada Raden Saleh Bantau yang dengan ikhlas menyediakan waktu dan lahan untuk dijadikan lokasi pengabdian.

\section{DAFTAR PUSTAKA}

Badan Pusat Statistik. (2019). Provinsi Sulawesi Tengah Dalam Angka (pp. 1-635). https://sulteng.bps.go.id/publication/2019/ 08/16/db05cef887cda1380a8829af/provin si-sulawesi-tengah-dalam-angka2019.html
Ban, A.W.V.D dan Hawkins, H.S. (1999). Penyuluhan Pertanian. Kanisius.

Cahyono, B., \& Adhiatma, A. (2012). Peran Modal Sosial Dalam Peningkatan Kesejahteraan Masyarakat Petani Tembakau Di Kabupaten Wonosobo. Conference In Business, Accounting, And Management (CBAM), 1(1), 131-144.

Hasibuan, A. M., Nurmalina, R., \& Wahyudi, A. (2012). Analisis Kinerja dan Daya Saing Biji Kakao dan Produk Kakao Olahan di Pasar Internasional. Buletin RISTRI, 3(1), 57-70. https://doi.org/10.2307/2585477

Managanta, A. A., Sumardjo, Sadono, D., \& Tjitropranoto, P. (2018a). Influencing Factors the Interdependence of Cocoa Farmers in Central Sulawesi Province, Indonesia. International Journal of Progressive Sciences and Technologies (IJPSAT), 8(1), 106-113. ijpsat.ijshtjournals.org/ index.php/ ijpsat/ article/view/ 394/210

Managanta, A. A., Sumardjo, Sadono, D., \& Tjitropranoto, P. (2018b). Interdependence of Farmers and Increasing Cocoa Productivity in Central Sulawesi Province, Indonesia. Journal of Economics and Sustainable Development, 9(6), 98-108. https://www.iiste.org/Journals/index.php/J EDS/article/view/41688\%0A

Managanta, A. A., Sumardjo, Sadono, D., \& Tjitropranoto, P. (2018c). Kemandirian Petani dalam Meningkatkan Produktivitas Usahatani Kakao di Provinsi Sulawesi Tengah.

Https://Repository.Ipb.Ac.Id/Handle/1234 56789/93841, 1-279. https://repository.ipb.ac.id/handle/123456 789/93841

Managanta, A. A., Sumardjo, Sadono, D., \& Tjitropranoto, P. (2019). Factors Affecting the Competence of Cocoa Farmers in Central Sulawesi Province. 15(1). https://doi.org/https://doi.org/10.25015/pe nyuluhan.v15i1.20966

Salleh, K. M., Khalid, N. H., Sulaiman, N. L., Mohamad, M. M., \& Sern, L. C. (2015). Competency of Adult Learners in Learning: Application of the Iceberg Competency Model. Procedia - Social and Behavioral Sciences, 204(November 2014), 326-334. https://doi.org/10.1016/j.sbspro.2015.08.1 60

Sumardjo. (1999). Transformasi Penyuluhan 
Pertanian menuju Pengembangan Kemandirian Petani (pp. 1-372). Institut Pertanian Bogor.

Sumardjo. (2006). Konfrensi Nasional
Penyuluhan dan Komunikasi Pembangunan. Kearifan Lokal Alternatif Menuju Modernisasi Dalam Penyuluhan Pembangunan, 1-659. 